Rev. Bras. Reprod. Anim., v.44, n.3, p.108-115, jul./set. 2020

\title{
Substituição parcial do soro fetal bovino durante cultivo in vitro reduz a concentração de fosfolipídios em embriões bovinos produzidos in vitro \\ Partial replacement of fetal bovine serum during in vitro culture decreases phospholipid content in in vitro produced bovine embryos
}

\author{
Carolina Gennari Verruma ${ }^{1 *}$, Anderson Mioranza ${ }^{2}$, Tânia Petta ${ }^{3}$, Reginaldo Aparecido Vila ${ }^{1}$, \\ Cristiana Libardi Miranda Furtado ${ }^{4}$, Luiz Alberto Beraldo de Moraes ${ }^{5}$, Raysildo Barbosa Lôbo ${ }^{1}$. \\ ${ }^{1}$ Department of Genetics, Ribeirão Preto Medical School, Ribeirão Preto, SP, Brazil. \\ ${ }^{2}$ Biovita, Cascavel, PR, Brazil. \\ ${ }^{3}$ Department of Biochemistry and Immunology, Ribeirão Preto Medical School, Ribeirão Preto, SP, Brazil. \\ ${ }^{4}$ Drug Research and Development Center, Postgraduate Program in Medical and Surgical Sciences, Federal \\ University of Ceara, CE, Brazil. \\ ${ }^{5}$ Department of Chemistry, Faculty of Philosophy, Science and Language Science at Ribeirão Preto, Ribeirão Preto \\ SP, Brazil. \\ *Departamento de Genética, Faculdade de Medicina de Ribeirão Preto, Ribeirão Preto, SP, Brasil. Avenida \\ Bandeirantes, 3900; 14049-900
}

\begin{abstract}
Resumo
Soro fetal bovino (SFB) e albumina sérica bovina (BSA) são componentes importantes do cultivo in vitro (CIV) de embriões bovinos, porém são frequentemente associados ao acúmulo excessivo de lipídios, podendo prejudicar o desenvolvimento embrionário. Este estudo teve como objetivo substituir parcialmente o SFB por BSA V FAF durante o CIV de embriões bovinos, avaliar a produção embrionária e quantificar os lipídios dos embriões, SFB e dos meios de cultivo. Para isto, os embriões desenvolveram em meios de cultivo suplementados com $10 \%$ de SFB (SFB10\%) ou $5 \%$ de SFB e $0.03 \mathrm{~g}$ de BSA V FAF (SFB5\%/BSA). $\mathrm{O}$ conteúdo lipídico foi avaliado por UHPLC-MS/MS. A análise estatística foi feita utilizando teste $\mathrm{t} e$ ANOVA. A substituição parcial de SFB por BSA V FAF não alterou a produção embrionária. Nos dois grupos foram identificados 10 fosfolipídios e três deles, DOPC $(p=0,037)$, POPG $(p=0,046)$ e C24: 1-SM $(\mathrm{p}=0,009)$, apresentaram menores concentrações no meio SFB5\%/BSA. Os fosfolipídios identificados nos embriões coincidem com os encontrados no SFB e meios de cultivo e quatro deles DOPC $(\mathrm{p}=0,013)$, DPPC $(\mathrm{p}=0,004)$, POPG $(\mathrm{p}=0,05)$ e C24:1-SM $(\mathrm{p}=0,003)$ diminuíram a concentração com a redução do SFB. A substituição parcial do SFB diminui a concentração de fosfolipídios sem prejudicar a produção embrionária, sugerindo uma melhora nas técnicas relacionadas ao cultivo in vitro.
\end{abstract}

Palavras-chave: Embriões bovinos; Produção in vitro (PIV); Fosfolipídios; UHPLC-MS/MS

\begin{abstract}
Fetal bovine serum (FBS) and bovine serum albumin (BSA) are important components during bovine embryo in vitro culture (IVC), but they are associated with excess of embryonic lipid, which might impair embryo development. This study aimed to partially replace FBS by BSA V FAF during bovine $I V C$, evaluate embryo production and quantify the phospholipid content in produced embryos, SFB and IVC medium. The embryos were in vitro cultured in medium supplied with $10 \%$ of FBS (FBS10\%) or with $5 \%$ of FBS plus $0.03 \mathrm{~g} B S A$ V FAF (FBS5\%/BSA). The lipid content was evaluated using UHPLC-MS/MS and statistical analysis was performed using $t$-test and ANOVA. The partial replacement of FBS by BSA $V$ FAF did not alter embryo production. Ten phospholipids were identified in both groups and three of them, DOPC ( $p=0.037), P O P G(p=0.046)$ and C24: 1-SM $(p=0.009)$ presented lower concentration in $F B S 5 \% / B S A$ culture medium. The phospholipids identified on embryos matches with those found on SFB and culture medium and four of them DOPC ( $p=0.013), D P P C(p=0.004), P O P G(p=0.05)$ and C24:1$S M(p=0.003)$ reduced its concentration when FBS was reduced. Theses founds shown that the FBS partial replacement reduces phospholipids content in embryos but do not decrease embryo production, suggesting a technical improvement.
\end{abstract}

Keywords: Bovine embryo; In vitro production (IVP); Phospholipids; UHPLC-MS/MS

1Correspondência: verruma.cg@usp.br

Recebido: 04 de setembro de 2019

Aceito: 16 de abril de 2020 
Verruma et al. Substituição parcial do soro fetal bovino durante cultivo in vitro reduz a concentração de fosfolipídios em embriões bovinos produzidos in vitro

\section{Introduction}

Assisted reproductive technologies (ARTs) are frequently used in domestic animals and a high number of bovine embryos are produced annually, but these techniques still reduce the quality and embryo rate production (Cagnone and Sirard, 2014). The development of a zygote until blastocyst stage during in vitro culture (IVC) is considered the most critical period of in vitro production (IVP) of embryos (Lonergan et al., 2003). This stage requires exogenous components such as fetal bovine serum (FBS) and bovine serum albumin (BSA) that stimulate cell proliferation and differentiation (Varago et al., 2008).

Although FBS is considered important to embryo development, it has been shown that its presence on IVC increased $30 \%$ of embryo lipid concentration on day 6 of development (Leroy et al., 2005). The FBS may influence the embryo lipids uptake by changing the mitochondria metabolism (Abe et al. 2002; Pereira e Marques, 2008) leading to an abnormal accumulation of long chain saturated and unsaturated lipids in the cytoplasm, which may impair the embryonic development (Abe et al., 2004). Furthermore, the presence of FBS during IVC could alter the concentration, function and chemical property of phospholipids that are important to embryo development, with an essential role in the membrane fluidity and permeability (Edidin, 2003; Pitangui-Molina et al., 2017).

It has been shown that in vitro produced embryos seem to be more sensitive to cryopreservation when compared with embryos in vivo produced, due to the higher concentration of lipid droplets found in in vitro embryos (Sanches et al., 2013). The components captured by the embryo during IVC seems to influence its quality. Small changes in the IVC medium can significatively increase the quality of the produced embryos and it has already been shown that lower lipids content is beneficial for embryo survival, facilitating its storage, transport and trade (Varago et al., 2008). Based on FBS published data (Lonergan et al., 2003; Rizos et al., 2003; Abe et al., 2004; Gómez et al., 2008), we hypothesize that partial replacement of FBS during embryo culture reduces lipid content without impair embryo production and that FBS may be the phospholipid source to embryo during IVC. Therefore, this paper aimed to partially replace FBS by BSA V FAF during IVC and evaluate embryo production and phospholipid concentration on embryos, FBS and both IVC medium.

\section{Material and Methods}

\section{In vitro production of bovine embryos}

All experiments were performed on Medical School of Ribeirão Preto, SP (FMRP-USP), Brazil. The ovaries were collected from slaughtered cows. Follicles between 2-8 mm were aspirated using an 18gauge needle connected to a $10 \mathrm{~mL}$ syringe. The oocytes were classified according to Leibfried and First (1979) and only those with more than three cumulus cells layers and homogenous ooplasm, grade I (GI) oocytes, were selected. The experiments were carried out in six replicates and a total of 946 cumulus oocytes complex (COCs) were selected. The oocytes were placed in microdrops (20 oocytes/microdrop) of $100 \mu \mathrm{L}$ of in vitro maturation (IVM) medium [TCM199 with Earle's salts, glutamine, $\mathrm{NaHCO}_{3}$ pyruvate $(22 \mu \mathrm{g} / \mathrm{mL}), 10 \%$ of FBS, FSH $(0.5 \mathrm{mg} / \mathrm{mL}), \mathrm{LH}(50 \mu \mathrm{g} / \mathrm{mL})$, amikacin $(83 \mu \mathrm{g} / \mathrm{mL})$, and estradiol $(1.0 \mu \mathrm{g} / \mathrm{mL})]$, during $22-24$ hours, in maximum humidity, at $38.8{ }^{\circ} \mathrm{C}$ and $5 \% \mathrm{CO}_{2}$.

At the end of IVM, the oocytes were transferred to in vitro fertilization (IVF) medium (TALP supplemented with heparin $(10 \mathrm{mg} / \mathrm{mL})$, pyruvate $(22 \mu \mathrm{g} / \mathrm{mL})$, BSA FAF (Fatty acid free) $(6 \mu \mathrm{g} / \mathrm{mL})$, and PHE solution ( $2 \mu \mathrm{M}$ of penicillamine, $1 \mu \mathrm{M}$ of hypotaurine, and $0.25 \mu \mathrm{M}$ of epinephrine) plus amikacin $(83 \mu \mathrm{g} / \mathrm{mL})$ with the sperm to IVF. Each drop contained approximately two million sperm per milliliter $(2$ $\times 10^{6} \mathrm{sperm} / \mathrm{mL}$ ). Gametes stayed on IVF medium during 12 hours in maximum humidity, at $38.8^{\circ} \mathrm{C}$ and $5 \% \mathrm{CO}_{2}$.

Twelve hours post-insemination, the presumptive zygotes were removed from the IVF medium, divided into two groups, (1) FBS10\% and (2) FBS5\%/BSA, and transferred to in vitro culture (IVC) medium (day zero, D0). The FBS10\% group developed in CR2 stock culture medium (Rosenkrans et al., 1993) supplemented with $10 \%$ of FBS, $0.03 \mathrm{~g}$ of BSA V (Fraction V), $100 \mu \mathrm{L}$ of alanine, $100 \mu \mathrm{L}$ of glycine and amikacin $(83 \mu \mathrm{g} / \mathrm{mL})$. The FBS5\%/BSA group was culture in the same medium mentioned above with a reduction of $50 \%$ of FBS (only $5 \%$ of FBS) and addition of $0.03 \mathrm{~g}$ of BSA V FAF. The 
Verruma et al. Substituição parcial do soro fetal bovino durante cultivo in vitro reduz a concentração de fosfolipídios em embriões bovinos produzidos in vitro

embryos were co-cultured in a cumulus cells monolayer system, without $\mathrm{O}_{2}$ control, in maximum humidity, at $38.8{ }^{\circ} \mathrm{C}$ and $5 \% \mathrm{CO}_{2}$. The embryo production rate was obtained at day 7 of development (D7) based on number of blastocysts in relation to zygotes (D0). Expanded blastocysts were selected to phospholipids analysis, in which 35 embryos from each group were pooled and evaluated in experimental triplicate. Embryos were stored in $100 \mu \mathrm{L}$ of $0.9 \%$ saline solution at $-80^{\circ} \mathrm{C}$ until phospholipid analysis.

\section{Phospholipid analysis}

The phospholipid analysis was performed on expanded blastocysts from both FBS10\% and FBS5\%/BSA groups. To observe the phospholipids concentration in the medium components, $500 \mu \mathrm{L}$ of FBS alone and the CR2 medium supplemented with FBS10\% (CR2-FBS10\%) or FBS5\%/BSA (CR2FBS5\%/BSA) were evaluated.

Total lipid extraction was made following protocol adapted from Bligh and Dyer (1959). On each sample were added $250 \mu \mathrm{L}$ of methanol $(\mathrm{MeOH})$ and $125 \mu \mathrm{L}$ of chloroform, and the solution was sonicated (four times, ten seconds each). Then, $100 \mu \mathrm{L}$ of water and $125 \mu \mathrm{L}$ of chloroform were added, shaking using a vortex. The sample was centrifuged for one minute at $1200 \mathrm{x} g$ and two phases could be observed (upper phase: aqueous; lower organic phase: chloroform). The lower organic phase was carefully discarded, $250 \mu \mathrm{L}$ of chloroform was added to the upper aqueous phase and the sample was centrifuged for one minute (this step was repeat two times in order to extract the maximum amount of material). With the extract separated from the rest of the sample, $300 \mu \mathrm{L}$ of $\mathrm{NaCl}$ was added to the aqueous phase to prevent emulsion formation. The resulting organic layer was exposed to gas nitrogen to dry it. Samples were resuspended in $100 \mu \mathrm{L}$ of $\mathrm{MeOH}$, and an aliquot of $1 \mathrm{~mL}$ was injected to the UHPLC-MS/MS system.

\section{Phospholipid identification by UHPLC-MS/MS}

The ultra-high-performance liquid chromatography by mass spectrometry (UHPLC-MS/MS) analysis of phospholipids was performed in an Acquity Ultra Performance Liquid Chromatographer HClass (Waters Corp., Milford, MA, USA) interfaced with the Xevo TQ-S mass spectrometer equipped with an orthogonal Z-spray electrospray ionization source (Waters Corp., Milford, MA, USA). The analyses were detected in the Multiple Reaction Monitoring scan mode (MRM) that is the most specific and accurate method based on the selection of certain precursor ions and their fragments. To optimize the analytical pure standards of phospholipids at $50 \mathrm{ng} / \mathrm{mL}$ was diluted in water/acetonitrile $(1: 1, \mathrm{v} / \mathrm{v})$, ammonium acetate at $10 \mathrm{mM}$ and introduced into the mass spectrometer by infusion at a flow of 10 $\mu \mathrm{L} / \mathrm{min}$ and submitted to the fragmentation by CID (Collision Induced Dissociation) with argon. The experimental parameters used were: capillary voltage: $2.30 \mathrm{~V}$; source temperature: $150{ }^{\circ} \mathrm{C}$; desolvation temperature: $350{ }^{\circ} \mathrm{C}$; cone gas flow: $150 \mathrm{~L} / \mathrm{h}$; desolvation gas flow: $500 \mathrm{~L} / \mathrm{h}$; collision gas flow: 0.15 $\mathrm{m} / \mathrm{L}$; nebulizer gas pressure: 7.00 bar; MRM transition cycle of $3.10^{-3} \mathrm{~s}$.

The electrospray ionization source (ESI) operated in both the positive and negative modes. The data obtained were processed in Masslynx 4.1 software (Waters Corporation, Milford, MA, USA) and are shown in supplementary material (Figure S1). The employed method was capable of identify 25 phospholipids classes. The phospholipid standards employed were described on supplementary table S1. For the chromatographic separation of compounds an UPLC BEH columns C4, (Waters Corporation, Milford, MA, USA) with dimensions of $1.7 \mu \mathrm{m}, 50 \times 2.1 \mathrm{~mm}$ was employed. The elution of compounds was carried out by means of a binary gradient where phase A consisted of water/ammonium acetate 10 $\mathrm{mM}$ and phase $\mathrm{B}$ was acetonitrile ammonium acetate $10 \mathrm{mM}$. The elution gradient was varied in the following proportion: $50 \% \mathrm{~B}$ in $0 \mathrm{~min}, 70 \% \mathrm{~B}$ in $8.0 \mathrm{~min}, 100 \% \mathrm{~B}$ of $8.5 \mathrm{~min}$ to $10.5 \mathrm{~min}$ and $50 \% \mathrm{~B}$ from 11.0 until $15.0 \mathrm{~min}$. The flow rate used was $0.5 \mathrm{~mL} / \mathrm{min}$ The parameters used for phospholipids analysis on UHPLC-MS/MS chromatograms in the MRM scan mode are shown in Table S2 and Figure S2 (Supplementary material).

The positive identification of a lipid species in the samples was accomplished by matching the MRM transition and retention time of the corresponding phospholipid standard. Comparison of phospholipid levels in the samples was accomplished by analysis of the relative intensities of the analytical signal of the identified phospholipids in the studied samples. 
Verruma et al. Substituição parcial do soro fetal bovino durante cultivo in vitro reduz a concentração de fosfolipídios em embriões bovinos produzidos in vitro

Statistical analysis

Statistical analysis was performed to evaluate the embryo production, phospholipids concentration on embryos cultured with FBS10\% and FBS5\%/BSA, FBS, CR2-FBS10\% and CR2FBS5\%/BSA medium. The mean differences were compared using t-test and Oneway ANOVA (Analysis of Variance) with post-hoc Tukey for multiple comparisons. All statistical analyses were carried out using SPSS 22 (IBM®, USA) software with a significance level of $5 \%(\mathrm{p}<0.05)$.

Embryo production

\section{Results}

The in vitro production of embryos was not affected $(\mathrm{p}=0.467)$ by the partial replacement of FBS by BSA, as the percentage of produced embryos was $46.46 \% \pm 7.4$ in the FBS10\% group and $43.03 \% \pm 5.0$ in the FBS5\%/BSA group. Furthermore, the rate of expanded blastocysts was also not affected $(\mathrm{p}=0.924)$ by the partial replacement of FBS by BSA (Tab 1$)$.

Tabela 1. Number of selected COCs and embryos cultured in FBS10\% and FBS5\%/BSA at the first day (D0) and seventh day (D7) of culture $(p<0.05)$.

\begin{tabular}{ccccc}
\hline Group & $\begin{array}{c}\text { Selected } \\
\text { COCs }\end{array}$ & Zygotes (D0) & $\begin{array}{c}\text { Embryo production (D7) n } \\
(\% \pm \text { SD) }\end{array}$ & $\begin{array}{c}\text { Expanded blastocysts } \\
\text { D7 n (\%) }\end{array}$ \\
\hline FBS10\% & \multirow{2}{*}{946} & 464 & $207(46.46 \pm 7.4)^{\mathrm{a}}$ & $170(82.1)^{\mathrm{a}}$ \\
FBS5\%/BSA & & 482 & $206(43.03 \pm 5.0)^{\mathrm{a}}$ & $174(84.4)^{\mathrm{a}}$ \\
\hline
\end{tabular}

Note: Different letters in the same column means statistical difference $(\mathrm{p}<0.05)$.

*Expanded blastocyst rates were calculated according to the total of blastocysts at D7.

COCs, cumulus-oocytes complex. FBS, fetal bovine serum. BSA, bovine serum albumin. D0, first day of culture. D7, seventh day of culture. SD, standard deviation.

\section{Phospholipids analyses}

A total of ten phospholipids were identified and quantified on expanded blastocysts from both FBS10\% and FBS5\%/BSA groups (Tab 2). The phospholipids DOPC ( $p=0.037)$, POPG $(p=0.046)$, and C24:1-SM $(p=0.009)$ were reduced in embryos cultured with FBS5\%/BSA when compared to embryos cultured with FBS10\% (Tab 2).

Tabela 2. Phospholipids content (area) in D7 embryos cultured with FBS10\% and FBS5\%/BSA $(p<0.05)$.

\begin{tabular}{cccc}
\hline Phospholipids $^{\mathbf{A}}$ & $\begin{array}{c}\text { FBS10\% } \\
\text { Mean } \pm \text { SD }\left(\mathbf{1 0}^{\mathbf{6}}\right)\end{array}$ & $\begin{array}{c}\text { FBS5\%/BSA } \\
\text { Mean } \pm \text { SD }\left(\mathbf{1 0}^{\mathbf{6}}\right)\end{array}$ & P value \\
\hline DMPE & $18.5 \pm 6.24$ & $40.9 \pm 3.24$ & 0.305 \\
DOPC & $1638.4 \pm 304.8$ & $989.9 \pm 198.0$ & $\mathbf{0 . 0 3 7}$ \\
DOPE & $110.3 \pm 48.1$ & $80.8 \pm 17.8$ & 0.376 \\
DPPC & $351.7 \pm 131.6$ & $255.3 \pm 64.6$ & 0.319 \\
POPC & $1969.2 \pm 718.5$ & $1395.9 \pm 286.3$ & 0.275 \\
POPE & $23.0 \pm 7.55$ & $18.1 \pm 4.63$ & 0.394 \\
POPG & $6.50 \pm 1.57$ & $3.07 \pm 1.37$ & $\mathbf{0 . 0 4 6}$ \\
PS & $44.8 \pm 21.0$ & $31.5 \pm 17.2$ & 0.445 \\
C18-SM & $127.5 \pm 45.1$ & $79.5 \pm 40.1$ & 0.240 \\
C24: $1-$ SM & $261.9 \pm 22.2$ & $139.1 \pm 39.5$ & $\mathbf{0 . 0 0 9}$ \\
\hline
\end{tabular}

Note: In bold, $p<0.05$.

*Phospholipids data were presented based on chromatograms areas.

$\mathrm{SD}$, standard deviation. D7, seventh day of culture.

AMPE: dilauroyl phosphatidylethanolamine. DOPC: dioleoyl phosphatidylcholine. DOPE: dioleoyl phosphatidylethanolamine. DPPC: dipalmitoyl phosphatidylcholine. POPC: 1-palmitoyl-2-oleoyl-sn-glycero-3phosphocholine. POPE: 1-palmitoyl-2-oleoyl-sn-3-phosphoethanolamine. POPG: 1-palmitoyl-2-oleoyl-sn-glycero-3[phospho-rac-(1-glycerol)]. PS: phosphatidylserine. C18-SM: N-(octadecanoyl)-sphinganine-1-phosphocholin. C24: 1-SM: N-(15Z-tetracosenoyl)-sphing-4-enine-1 phosphocholine 
Verruma et al. Substituição parcial do soro fetal bovino durante cultivo in vitro reduz a concentração de fosfolipídios em embriões bovinos produzidos in vitro

To evaluate the hypothesis that the phospholipids presented on embryos are also presented in the IVC medium, the FBS alone and both CR2-FBS10\% and CR2-FBS5\%/BSA medium were analyzed in the UHPLC-MS/MS. The same ten phospholipids found on embryos were found on FBS, CR2-FBS10\% and CR2-FBS5\%/BSA. Four of them, DOPC $(p=0.013)$, DPPC $(p=0.004)$, POPG $(p=0.05)$ and C24:1-SM $(p=0.003)$ showed reduced concentration in CR2-FBS5\%/BSA in relation to CR2-FBS10\% (Tab 3). It is important to observe that three phospholipids with reduced concentration (DOPC, POPG and C24:1-SM) on $\mathrm{CR} 2-\mathrm{FBS} 5 \%$ /BSA medium also presented lower concentration in embryos cultured in this medium.

Tabela 3. Phospholipids content (area) found on FBS singly, FBS10\% CR2 and FBS5\%/BSA CR2 medium. $(p<0.05)$.

\begin{tabular}{cccc}
\hline Phospholipids $^{\mathbf{A}}$ & $\begin{array}{c}\text { FBS } \\
\text { Mean } \pm \text { SD } \\
\left(\mathbf{1 0}^{\mathbf{6}}\right)\end{array}$ & $\begin{array}{c}\text { CR2-FBS10\% } \\
\text { Mean } \pm \text { SD } \\
\left(\mathbf{1 0}^{\mathbf{6}}\right)\end{array}$ & $\begin{array}{c}\text { CR2-FBS5\%/BSA } \\
\text { Mean } \pm \text { SD } \\
\left(\mathbf{1 0}^{\mathbf{6}}\right)\end{array}$ \\
\hline DMPE & $12024.89 \pm 4874.78^{\mathrm{a}}$ & $9029.57 \pm 2562.70^{\mathrm{a}}$ & $11269.77 \pm 1583.92^{\mathrm{a}}$ \\
DOPC & $12163.76 \pm 396.74^{\mathrm{a}}$ & $3821.95 \pm 211.03^{\mathrm{b}}$ & $2775.38 \pm 280.67^{\mathrm{c}}$ \\
DOPE & $42.59 \pm 3.75^{\mathrm{a}}$ & $46.93 \pm 57.72^{\mathrm{a}}$ & $7.71 \pm 1.36^{\mathrm{a}}$ \\
DPPC & $7063.87 \pm 144.57^{\mathrm{a}}$ & $1568.63 \pm 18.02^{\mathrm{b}}$ & $1005.19 \pm 166.88^{\mathrm{c}}$ \\
POPC & $8.99 \pm 1.77^{\mathrm{a}}$ & $1.36 \pm 0.36^{\mathrm{b}}$ & $0.45 \pm 0.40^{\mathrm{b}}$ \\
POPE & $44.35 \pm 1.44^{\mathrm{a}}$ & $19.24 \pm 15.48^{\mathrm{b}}$ & $5.02 \pm 1.02^{\mathrm{b}}$ \\
POPG & $76.16 \pm 2.54^{\mathrm{a}}$ & $25.55 \pm 9.70^{\mathrm{b}}$ & $10.69 \pm 3.94^{\mathrm{c}}$ \\
PS & $26.70 \pm 2.48^{\mathrm{a}}$ & $5.18 \pm 0.36^{\mathrm{b}}$ & $1.91 \pm 0.18^{\mathrm{b}}$ \\
C18-SM & $11115.91 \pm 796.78^{\mathrm{a}}$ & $1676.27 \pm 84.27^{\mathrm{b}}$ & $828.50 \pm 149.37^{\mathrm{b}}$ \\
C24: 1-SM & $17333.75 \pm 147.05^{\mathrm{a}}$ & $5772.75 \pm 728.06^{\mathrm{b}}$ & $3321.12 \pm 544.83^{\mathrm{c}}$ \\
\hline
\end{tabular}

Note: Different letters in the same line means statistical difference $(\mathrm{p}<0.05)$.

*Phospholipids data were presented based on chromatograms areas.

A DMPE: dilauroyl phosphatidylethanolamine. DOPC: dioleoyl phosphatidylcholine. DOPE: dioleoyl phosphatidylethanolamine. DPPC: dipalmitoyl phosphatidylcholine. POPC: 1-palmitoyl-2-oleoyl-sn-glycero-3phosphocholine. POPE: 1-palmitoyl-2-oleoyl-sn-3-phosphoethanolamine. POPG: 1-palmitoyl-2-oleoyl-sn-glycero-3[phospho-rac-(1-glycerol)]. PS: phosphatidylserine. C18-SM: N-(octadecanoyl)-sphinganine-1-phosphocholin. C24: 1-SM: N-(15Z-tetracosenoyl)-sphing-4-enine-1 phosphocholine. SD, standard deviation.

\section{Discussion}

One frequent issue related to the use of FBS during IVP is the embryo lipid amount after in vitro culture (IVC). Our results shown that the partial replacement of FBS by BSA V FAF promotes a reduction of the phospholipids DOPC, POPG and C24:1-SM on expanded blastocysts, without impair the production rate. We observed that embryo production on $\mathrm{D} 7$ were about $40 \%$ in both tested groups what is consistent with the results published in the literature (Viana et al., 2012). The comparison of our results with literature data, shows that partial protein replacement seems to be more adequate than full substitution, since full FBS replacement by BSA during oocyte maturation and embryo culture decreased embryo production (Sena-Netto et al., 2020). One major challenge in IVP is to develop an appropriate growth medium, which mimics the essential components to the proper development of the embryo, reducing cell stress, loss of viability and allowing a technical improvement (Gómez et al., 2008; Cagnone and Sirard, 2014).

FBS and BSA are important components to embryonic early development and are often used during IVC (Crocco et al., 2013). The presence of FBS on IVC stimulates embryo development until blastocyst stage, albeit also influences the lipid content and impair embryo survival after cryopreservation (Rizos et al., 2003; Sudano et al., 2011). Several studies mentioned the relationship between lipid content on embryos and their influence in the success rate of ARTs and other related process. Among them, Sudano and colleagues (2012) showed that membrane phospholipids, for example, can be specie-specific and change its composition according to culture microenvironment, which may result on changes in membrane fluidity and embryo cryosurvival rate. It is clear that lipid metabolism is essential to mammal development (Ferreira et al., 2014) and has fundamental role in energy storage, cell structure and cell physical and metabolic changes (Sudano et al., 2012). Therefore, the quantification and classification of lipids present on embryos are important to understand the embryo metabolism, mainly those produced by 
Verruma et al. Substituição parcial do soro fetal bovino durante cultivo in vitro reduz a concentração de fosfolipídios em embriões bovinos produzidos in vitro

ARTs (Sudano et al., 2012; Melo et al., 2014).

Consistent with published literature (Sudano et al., 2011), our findings demonstrated that a 50\% reduction of FBS on IVC did not alter embryo production. Although there was no difference in production rate, the reduction of FBS in the culture medium changed the phospholipids concentration on embryos. The concentrations of DOPC, POPG and C24:1-SM were higher in the FBS10\% compared to FBS5\%BSA group. Phospholipids play an important role during and after fertilization, being the major lipid class present in eukaryotic cell membranes (McEvoy et al., 2000; Annes et al., 2019). Preimplantation embryos have higher-mass lipids, such as ceramides, whereas the zona pellucida contains lower-mass lipids such as phosphatidic acid derivatives and phosphatidylethanolamides (Ferreira et al., 2014).

The phospholipids, such as the phosphatidylcholine (DOPC) and sphingomyelin (C24:1-SM) found reduced in the FBS5\%/BSA group are structural lipids and membranes components with important role to embryo development, survival rate after cryopreservation techniques and pregnancy success due to its main influence in membrane signaling (Annes et al., 2019). Phosphatidylcholines (DOPC, DPPC and POPC, for example) are the most abundant phospholipids in eukaryotic cell membrane, important to embryogenesis, which may act like a cell messenger and play a role in apoptosis process. Besides that, this phospholipid class is important to endoplasmic reticulum biogenesis, an essential organelle to embryo development (Albi and Viola Magni, 2004; Vance and Vance, 2004; Diez et al., 2005). The sphingomyelins (C18-SM and C24: 1-SM) are structural lipids that participates of cellular signaling and its metabolism products such as ceramides and diacylglycerol, as well as the phosphatidylcholine, may influence cell functions, including cell proliferation and apoptosis (Paula-Lopes and Hansens, 2002; Leão et al., 2014). Furthermore, the sphingomyelins are part of functional membranes and influence membrane permeability and fluidity during temperature changes (Edidin, 2003; Sudano et al., 2012). Still, sphingomyelins could assist nuclear organization during cell division (Albi and Viola Magni, 2004).

To evaluate the hypothesis that the lipids found in bovine embryos are from FBS present in the IVC, we evaluated the phospholipid content of FBS alone and CR2 medium with FBS10\% (CR2FBS10\%) and FBS5\%/BSA (CR2- FBS5\%/BSA). The UHPLC-MS/MS analysis identified the same ten phospholipids found on embryos. Four of them, DOPC, DPPC, POPG and C24:1-SM are phosphatidylcholines, phosphoglycerol and sphingomyelins, respectively, that reduced its concentration on CR2-FBS5\%/BSA when compared to CR2-FBS10\%. These results are in accordance with Vireque and colleagues (2017) that showed by MALDI-MS method that FBS has elevated phospholipid concentration, specially phosphatidylcholines and sphingomyelins. In addition, three of four phospholipids (DOPC, POPG and C24:1-SM) that presented lower concentrations in CR2-FBS5\%/BSA medium were also reduced on embryos that were cultured on it. This corroborate with studies that highlighted the influence of culture medium components during embryo early development such as lipid content (Leroy et al., 2005; Pereira and Marques, 2008).

Despite the importance of the observed results, a limitation of this study was that we did not evaluate if the phospholipid concentration reduction in the FBS5\%/BSA group could improve embryo survival rate after cryopreservation. To our knowledge, any study evaluated the association between FBS and phospholipid concentration in embryos cultured in CR2 culture medium with a co-culture system with cumulus cell monolayer and without an $\mathrm{O}_{2}$ control. Although the studied phospholipids are essential to cell function, structure and organization, their reduction seems not to impair embryo development as observed in production rate results, suggesting that the embryo may capture essential nutrients to its development in other components available in the medium.

In conclusion, the partial replacement of FBS by BSA V FAF reduced the phospholipid content without changing the final embryo production. In addition, the results reinforce the idea that FBS may provide lipids sources to bovine embryos during IVP, since it was identified the same phospholipids on embryos and FBS. Finally, the partial replacement of the FBS reduced the concentration of the same phospholipids on IVC medium and embryos. These results may suggest an improvement of techniques related to IVC, since the reduction of lipid concentration on bovine embryos may increase resistance, improving its survivor and viability.

\section{Acknowledgenments}

This work was supported by Fundação de Amparo à Pesquisa do Estado de São Paulo (FAPESP; Process $N^{\circ}$ 2012/22672-8) and Associação Nacional de Criadores e Pesquisadores (ANCP). 
Verruma et al. Substituição parcial do soro fetal bovino durante cultivo in vitro reduz a concentração de fosfolipídios em embriões bovinos produzidos in vitro

\section{References}

Abe H, Yamashita S, Satoh T, Hoshi H. Accumulation of cytoplasmic lipid droplets in bovine embryos and cryotolerance of embryos developed in different culture systems using serum-free or serumcontaining media. Mol Reprod Dev, v.61, p.57-66, 2002.

Abe H, Shiku H, Aoyagi S, Hoshi H. Review. In vitro culture and evaluation of embryos for production of high quality bovine embryos. J Mam Ova Res, v.21, p.22-30, 2004.

Albi, E, Viola Magni MP. The role of intranuclear lipids. Biol Cell. v.96, p.657-667, 2004.

Annes K, Sudano MJ, Belaz KRB. Lipid characterization of in vitro-produced bovine embryos with distinct kinects of development. Zygote, p.1-10, 2019.

Bligh E, Dyer WJ. A rapid method for total lipid extraction and purification. Can J Biochem Physiol, v.37, p.911-917, 1959.

Cagnone G, Sirard MA. The impact of exposure to serum lipids during in vitro culture on the transcriptome of bovine blastocysts. Theriogenology, v.81, p.712-722, 2014.

Crocco MC, Kelmansky DM, Mariano, MI. Does serum cause lipid-droplet accumulation in bovine embryos produced in vitro, during developmental days 1 to 4. J of Assist Reprod and Gen; Published online, p.12, 2013. DOI 10.1007/s10815-013-0060-8

Diez C, Duque P, Gómez E, Hidalgo CE, Tamargo C, Rodríguez A, Fernández L, de la Varga S, Fernández A, Facal N, Carbajo M. Bovine oocyte vitrification before or after meiotic arrest: effects on ultrastructure and development ability. Theriogenology, v.64, p.317-333, 2005.

Edidin M. Review. Lipids on the frontier: a century of cell-membrane bilayers. Nature: Mol Cell Biol, v.4, p.414-418, 2003.

Ferreira MS, Oliveira DN, Gonçalves RF, Catharino RR. Lipid characterization of embryo zones by silica plate laser desorption ionization mass spectrometry imaging (SP-LDI-MSI). Anal Chim Acta, v.807, p.96-102, 2014.

Gómez E, Rodríguez A, Muñoz M., et al. Serum free embryo culture medium improves in vitro survival of bovine blastocysts to vitrification. Theriogenology, v.69, p.1013-1021, 2008.

Leão BCS, Rocha-Frigoni NAS, Cabral EC, Franco MF, Ferreira CR, Eberlin MN, Filgueiras PL, Mingoti GZ. Membrane lipid monitored by mass spectrometry detected differences between fresh and vitrified in vitro-produced bovine embryos. Zygote, p.1-10, 2014.

Leibfried L, First NL. Characterization of bovine follicular oocytes and their ability to mature in vitro. J Anim Sci, v.48, p.76-86, 1979.

Leroy JLMR, Genicot G, Donnay I, Van Soom A. Evaluation of the lipid content in bovine oocytes and embryos with nile red: a pratical approach. Reprod Dom Anim, v.40, p.76-78, 2005.

Lonergan P, Rizos D, Kanka J, Nemcova L, Mbaye AM, Kingston M, Wade M, Duffy P, Bolland MP. Temporal sensitivy of bovine embryos to culture environment after fertilization and the implications for blastocyst quality. Reproduction, v.126, p.337-346, 2003.

McEvoy TG, Coull GD, Broadbent PJ, Hutchinson JSM, Speake BK. Fatty acid composition of lipids in immature cattle, pig and sheep oocytes with intact zona pellucida. J Reprod Fertil, v.188, p.163-170, 2000 .

Melo DH, Nascimento MZ, Oliveira DL, Neves LA, Annes K. Algorithms for automatic segmentation of bovine embryos produced in vitro. J Phy: Conf Ser, 490, p.4, 2014.

Paula-Lopes FF, Hansen PJ. Heat shock-induced apoptosis in preimplantation bovine embryos is a developmentally regulated phenomenon. Biol Reprod, v.66, p.1169-1177, 2002.

Pitangui-Molina CP, Vireque AA, Tata A, Belaz KRA, Santos VG, Eberlin MN, Silva-de-Sá MF, Ferriani RA, Silva ACJSR. Effect of soybean phosphatidylcholine on lipid profile of bovine oocytes matured in vitro. Chem Phys Lipids, v.204, p.76-84, 2017.

Pereira RM, Marques CC. Animal oocyte and embryo cryopreservation. Cell Tissue Bank, v.9, p.267277, 2008.

Rizos D, Gutiérrez-Adán A, Pérez-Garnelo S, et al. Bovine embryo culture in the presence or absence of serum: Implications for blastocysts development, cryotolerance, and Messenger RNA expression. Biol Reprod, v.68, p.236-243, 2003.

Rosenkrans Jr CF, Zeng GQ, McNamara GT, Schoff PK, First NL. Development of bovine embryos in vitro as affected by energy substrates. Biol Reprod, v.49, p.459-462, 1993. 
Verruma et al. Substituição parcial do soro fetal bovino durante cultivo in vitro reduz a concentração de fosfolipídios em embriões bovinos produzidos in vitro

Sanches BV, Marinho LSR, Filho BDO, Pontes JHF, Basso AC, Meirinhos MLG, Silva-Santos KC, Ferreira CR, Seneda MM. Cryosurvival and pregnancy rates after exposure of IVF-derived Bos indicus embryos to forskolin before vitrification. Theriogenology, v.80, p.372-377, 2013.

Sena-Netto SB, Sprígido JFW, Leme LO, Guimarães ALS, Caixeta FMC, Dode MAN, Pivato I. The replacement of fetal bovine sérum with bovine serum albumin during oocyte maturation and embryo culture does not improve blastocyst quality after slow freezing cryopreservation. Biopreserv Biobank, v.18, p.171-179, 2020.

Sudano MJ, Paschoal DM, Rascado TS, Magalhães LCO, Crocomo LF, Lima-Neto JF, LandimAlvarenga FC. Lipid content and apoptosis of in vitro- produced bovine embryos as determinants of susceptibility to vitrification. Theriogenology, v.75, p.1211-1220, 2011.

Sudano MJ, Santos VG, Tata A, Ferreira CR, Paschoal DM, Machado R, Buratini J, Eberlin MN, Landim-Alvarenga FDC. Phosphatidylcholine and Sphingomyelin profiles vary in Bos taurus and Bos taurus taurus in vitro and in vivo produced blastocysts. Biol Reprod, v.87, p.1-11, 2012.

Vance JE, Vance DE. Phospholipid biosynthesis in mammalian cells. Biochem Cell Biol, v.82, p.113$128,2004$.

Varago FC, Mendonça LF, Lagares MA. Produção in vitro de embriões bovinos: estado da arte e perspectiva de uma técnica em constante evolução. Rev Bras Reprod Anim, v.32, p.100-109, 2008.

Viana JHM, Siqueira LGB, Palhao MP, Camargo LSA. Features and perspectives of the Brazilian in vitro embryo industry. Animal Reprod, v.9, p.12-18, 2012.

Vireque AA, Tata A, Belaz KRA, Grázia JGV, Santos FN, Arnold DR. MALDI mass spectrometry reveals that cumulus cells modulate the lipid profile of in vitro-matured bovine oocytes. Syst Biol Reprod Med, v.63, p.86-99, 2017. 